\title{
ORGANIZATIONS CITED IN TEXT
}

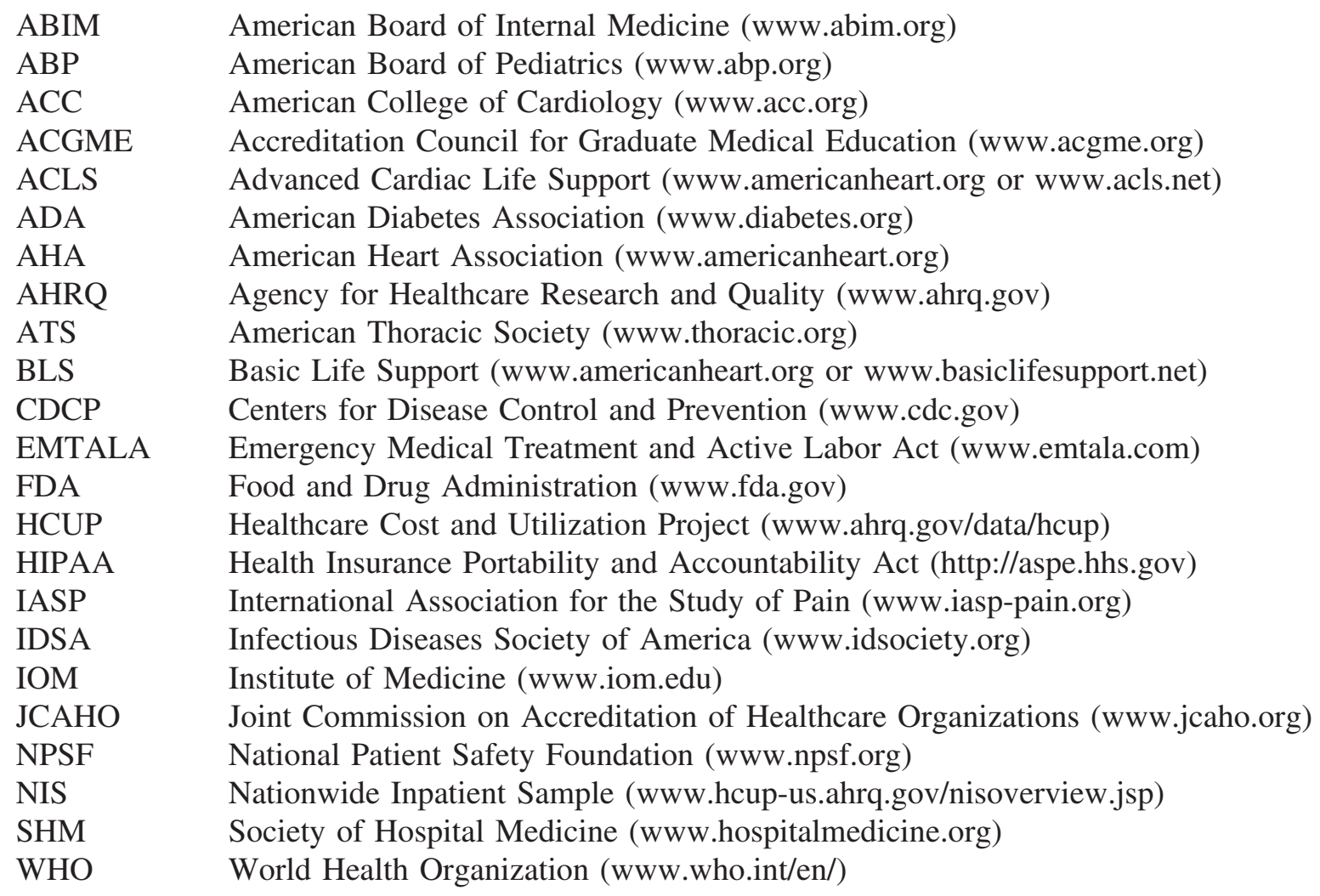

